\title{
"ANALYSING CORE THEMES AND CO-AUTHOR PATTERNS ON THE CONNECTION BETWEEN INTELLECTUAL PROPERTY RIGHTS AND SOCIAL ENTERPRISES"
}

\author{
Young-Chool Choi \\ (Professor, Department of Public Administration, Chungbuk National University, Korea) Contact: ycchoi@cbu.ac.kr
}

\begin{abstract}
:
This study focuses on deriving key issues relating to social enterprises and intellectual property rights using text mining methods, and analysing the co-author patterns of researchers working in these fields. For this purpose, the Netminer program was used to analyse journal papers published by Springer Publishing. As a result of the analysis, the research topics relating to social enterprises and intellectual property rights were, by way of a theoretical framework, classified according to nine issues: the management model of social enterprises; social enterprises and NGOs; the supply chain of social enterprises; the impact of social enterprises; environmental changes in social enterprises; social entrepreneurship; social enterprise and education; the social enterprise ecosystem; and social enterprises and NGOs.. These nine key issues represent areas of great importance in terms of business activities that link social enterprises and intellectual property rights. Contrastingly, examination of the co-author patterns of authors discussing social enterprises and intellectual property rights suggests that those employing multi-disciplinary approaches should engage more actively in joint research activities. Though such authors have achieved notable results to date, their engaging more actively in joint research activities should enhance the success of policies linking social enterprises and intellectual property rights.
\end{abstract}

Article Received: 18 October 2020, Revised: 3 November 2020, Accepted: 24 December 2020

\section{INTRODUCTION}

Today, social enterprise is an institution that a ddresses the weaknesses of the capitalist mark et economy, and academic studies exploring th is are being conducted in numerous countries. In addition, public officials in charge of soci al enterprises have been expending a great de al of effort on the enactment and revision of various laws, and the incentives and support $\mathrm{s}$ ystems for spreading these laws. In particular, in developing countries which are receiving a id from developed countries, technology to pro duce and sell is needed to start up social ente rprises and to operate them sustainably: in oth er words, practical skills are required for starti ng a business. In order to solve the problems attendant on this, it is necessary actively to provide technology for starting a business usin $\mathrm{g}$ the social enterprise support system. The tec hnologies that are required for developing cou ntries with low development levels are those a ppropriate to the specific case, not high-tech o nes. Appropriate technologies, as they are call ed, are not very powerful in terms of technol ogy, but involve vital real-life skills.

In order to provide such technology stably, it is necessary to utilize a great many intellectua 1 property rights, such as patents whose rights protection period has expired. For example, in a country that produces a lot of intellectual pr operty rights such as Korea, around 100,000 p atents are registered every year. As in many $f$ oreign countries, patents can be used by anyo ne after twenty years' registration. In other $w$ ords, then, the exclusive right of the patent $o$ wner is extinguished. For example, a technolo gy registered as a patent in 2000 becomes a $t$ echnology that anyone can use in 2020, twent $\mathrm{y}$ years later. Even technology registered in 2 000 in Korea can work in developing countrie s. This is because, for instance, in 2000, Kore a's per capita GDP was 1,400 dollars, while 
Vietnam's per capita GDP in 2020 was aroun d 2,500 dollars. In view of this logic, efforts to link intellectual property rights that can be used by anyone after a certain period of time of being registered in patent-developed countri es, including Korea, are of great importance ( Choi \& Kim, 2018; Corbett \& Fikkert, 2012; Cornish et al., 2010; Hurt \& Schuman, 1996).

Against this background, this study examines, first, what issues are involved in linking socia 1 enterprises and intellectual property rights. $S$ econd, following the assumption that strong ef forts to link social enterprises and intellectual property rights need to be made in academia, research trends to date are reviewed. Third, th e study analyses which researchers have work ed extensively on social enterprises and intelle ctual property rights, and what kind of pattern $s$ their writing shows. These research objective $s$ have numerous implications for strengthening the linkage of intellectual property rights wit $\mathrm{h}$ social enterprises in the future.

\section{RESEARCH PROBLEMS AND SURVEY DESIGN}

\subsection{Research problem}

A social enterprise is a company that provides a certain service to the socially underprivileg ed, employs numerous socially underprivileged workers, and at the same time strives to achi eve a social purpose rather than a profit purp ose. Since social enterprises are different from enterprises operating in the general market ec onomy, most countries provide a certain amou nt of support for them. These, for example, $m$ ay include a plan whereby government pays $t$ he labour costs of workers employed by socia 1 enterprises. In addition, the government or $g$ overnment companies purchase goods or servic es produced by social enterprises, and they als $\mathrm{o}$ provide administrative and financial incentiv es.

Government, then, provides support for social enterprises in various different ways (Mazzurc o \& Jesiek, 2017). But in reality, the biggest problem facing social enterprises is the lack o $\mathrm{f}$ technology helping them to produce. In orde $r$ to compensate for this, it is necessary for $b$ oth central and local government to provide a ssistance. Appropriate technology can be a go od alternative means of doing this. In other $w$ ords, if the intellectual property rights of deve loped countries are provided to the developing countries, and residents are supported to start social enterprises using these technologies, thi $\mathrm{s}$ can be a very good alternative means of im proving the lives of the citizens of developing countries (Hynes \& Scott, 2013;.

Nevertheless, very little research has been co nducted on social enterprises and intellectual $\mathrm{p}$ roperty rights (Polak \& Warwick, 2013). As a consequence, when social enterprises and inte llectual property rights are linked and utilized it is impossible to grasp what is at issue, whi ch weakens the sustainability of social enterpri ses. In addition, given that efforts to link soci al enterprises and intellectual property rights $s$ hould be further strengthened in the future, it is important to establish which researchers hav e been conducting research in this field, and what patterns have been shown when joint res earch has been conducted. Against this need $\mathrm{f}$ or problem recognition, this study has selected the following research questions:

1. What keywords can be discerned in the field of social enterprise and intellectu al property rights?

2. In the field of social enterprises and in tellectual property rights, how can impo rtant research topics be classified?

3. Which authors study the fields of socia 1 enterprise and intellectual property rig hts, and what patterns of joint research do they show? 


\subsection{Research design}

In order to solve the above-mentioned researc $\mathrm{h}$ problem, this study analyses academic paper $\mathrm{s}$ published in 145 journals in the social scien ce field managed by Springer Publishing. Of $t$ hese papers, only those that deal with social e nterprise and intellectual property rights in the same content are extracted and analysed. For keywords, we use social enterprise and intell ectual property. In other words, only papers c ontaining these terms are selected and analyse d. The analysis method chosen is text mining. Since this enables keyword analysis and topi c analysis targeting of unstructured documents, it is the method best-suited to achieving the a $\mathrm{i}$ m o f $\mathrm{t}$ h i s $\mathrm{s}$ t u d y Blei, 2012; Markus, 2018; Son, 2005; Turner et al. ,2013). In this study, three research objectives were put forward, and a combination of wor d cloud analysis, in-degree centrality, co-autho $r$ pattern analysis and topic analysis methods was used to achieve them.

\section{ANALYSIS RESULT}

\subsection{Topic analysis}

The papers dealing with intellectual property a nd social enterprise totalled 425. The keyword $\mathrm{s}$ included in these papers totalled 5,440 and $\mathrm{t}$ he number of authors 777 . The 30 words that occurred most frequently are presented in $\mathrm{Ta}$ ble 1 , in order of frequency. The word appear ing most frequently was business (326 occurre nces), followed by innovation (305 occurrences ).

Table 1: Frequency of occurrence of keywords

\begin{tabular}{|c|c|c|c|c|c|c|}
\hline & & 1 & 2 & 3 & 4 & 5 \\
\hline & & It of Speech $(\mathrm{PC}$ & Frequency & Word length & Name Type & Author Keywore \\
\hline 1 & business & Common Noun" & 326.0 & 8.0 & $\because$ & "False" \\
\hline 2 & innovation & Common Noun" & 305.0 & 10.0 & $\because$ & "False" \\
\hline 3 & development & Common Noun" & 238.0 & 11.0 & $\because$ & "False" \\
\hline 4 & entrepreneurship & Common Noun" & 198.0 & 16.0 & $\because$ & "False" \\
\hline 5 & model & Common Noun" & 158.0 & 5.0 & $\because$ & "False" \\
\hline 6 & technology & Common Noun" & 139.0 & 10.0 & $\because$ & "False" \\
\hline 7 & process & Common Noun" & 132.0 & 7.0 & $\because$ & "False" \\
\hline 8 & market & Common Noun" & 128.0 & 6.0 & $\because$ & "False" \\
\hline 9 & approach & Common Noun" & 124.0 & 8.0 & $\because$ & "False" \\
\hline 10 & knowledge & Common Noun" & 123.0 & 9.0 & $\because$ & "False" \\
\hline 11 & education & Common Noun" & 116.0 & 9.0 & $\because$ & "False" \\
\hline 12 & framework & Common Noun" & 114.0 & 9.0 & $\because$ & "False" \\
\hline 13 & service & Common Noun" & 112.0 & 7.0 & $\because$ & "False" \\
\hline 14 & challenge & Common Noun" & 111.0 & 9.0 & $\because$ & "False" \\
\hline 15 & country & Common Noun" & 109.0 & 7.0 & $\because$ & "False" \\
\hline 16 & policy & Common Noun" & 108.0 & 6.0 & $\because$ & "False" \\
\hline 17 & system & Common Noun" & 102.0 & 6.0 & $\because$ & "False" \\
\hline 18 & enterprise & Common Noun" & 101.0 & 10.0 & $\because$ & "False" \\
\hline 19 & strategy & Common Noun" & 100.0 & 8.0 & $\because$ & "False" \\
\hline 20 & value & Common Noun" & 98.0 & 5.0 & $\because$ & "False" \\
\hline 21 & role & Common Noun" & 98.0 & 4.0 & $\because$ & "False" \\
\hline 22 & organization & Common Noun" & 980 & 120 & $\because$ & "False" \\
\hline 23 & university & Common Noun" & 95.0 & 10.0 & $\because$ & "False" \\
\hline 24 & community & Common Noun" & 93.0 & 9.0 & $\because$ & "False" \\
\hline 25 & sector & Common Noun" & 92.0 & 6.0 & $\because$ & "False" \\
\hline 26 & management & Common Noun" & 92.0 & 10.0 & $\because$ & "False" \\
\hline 27 & entrepreneur & Common Noun" & 92.0 & 12.0 & $\because$ & "False" \\
\hline 28 & impact & Common Noun" & 90.0 & 6.0 & $\because$ & "False" \\
\hline 29 & change & Common Noun" & 89.0 & 6.0 & $\because$ & "False" \\
\hline 30 & resource & Common Noun" & 85.0 & 8.0 & $\because$ & "False" \\
\hline 31 & iesilo & Famman Nniın" & ALn & $5 \cap$ & $\because$ & "Falea" \\
\hline
\end{tabular}

Figure 1 represents a word cloud analysis of $t$ he words that appeared. The greater the frequ ency of occurrence of the word the larger its illustration will be, and the lower the frequenc $y$ of occurrence of the word the smaller its ill ustration will be. 


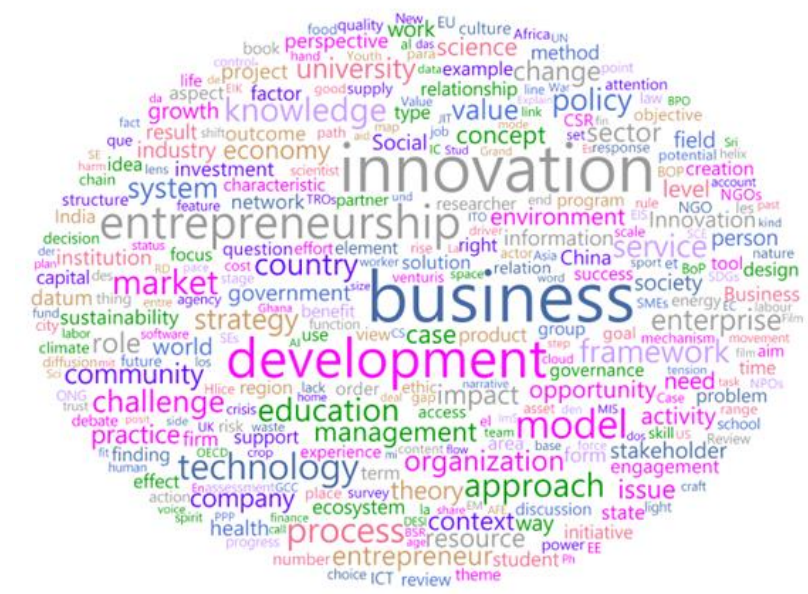

Figure 1: Word cloud analysis result

As a result of conducting thematic analysis us ing the words that appeared and the paper co ntaining the words, a total of ten topics were found. Figure 2 shows the results of this topi c analysis.
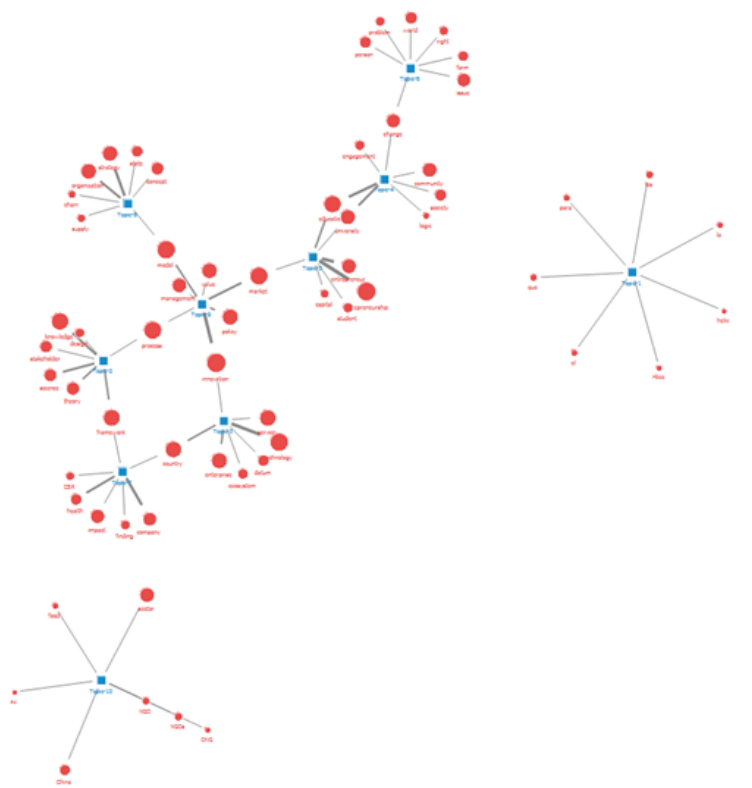

Figure 2 Results of topic analysis

The ten topics that appeared as a result of th e topic analysis will be explained individually. First, the Topic 1 is made up entirely of pre positions, which have very little thematic mea ning. Thus Topic 1 can be safely ignored, an $\mathrm{d}$ so will be excluded from this study, and it was deleted here..

Figure 3 shows Topic 2. Topic 2 consists of knowledge, framework, process, theory, stakeho lder, science and design. This may be said to be the 'theoretical framework for social enterp rise' topic. As social enterprises develop, theor ies relating to them emerge and continue to $\mathrm{s}$ pread.

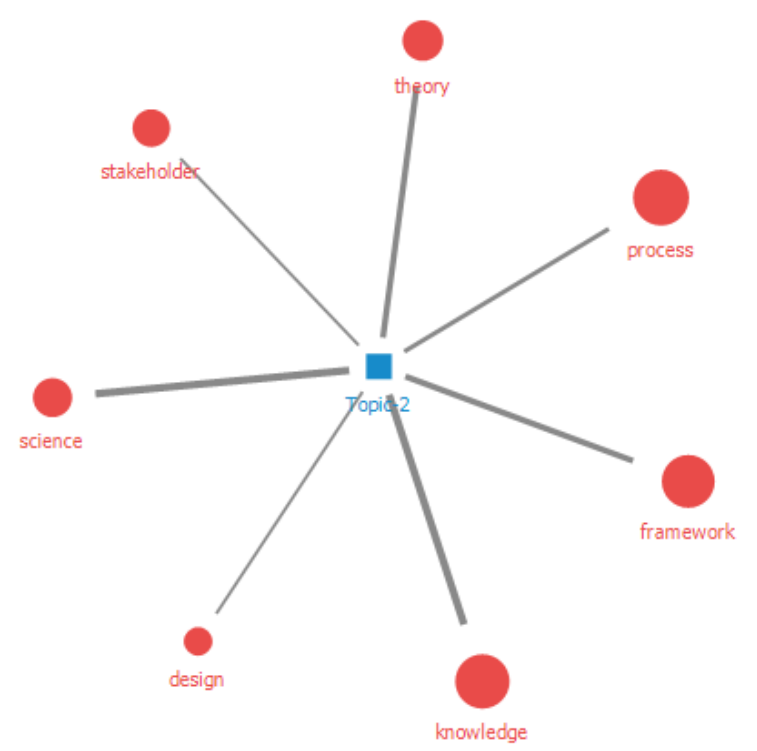

Figure 3:Topic 2: Theoretical framework for $\mathrm{s}$ ocial enterprise

Figure 4 shows Topic 3. Topic 3 consists of innovation, enterprise, ecosystem, service, coun try, datum and technology. This topic may be said to concern the ecosystem of social enter prises. It highlights the fact that in order for social enterprises to develop sustainably, such an ecosystem must be established.

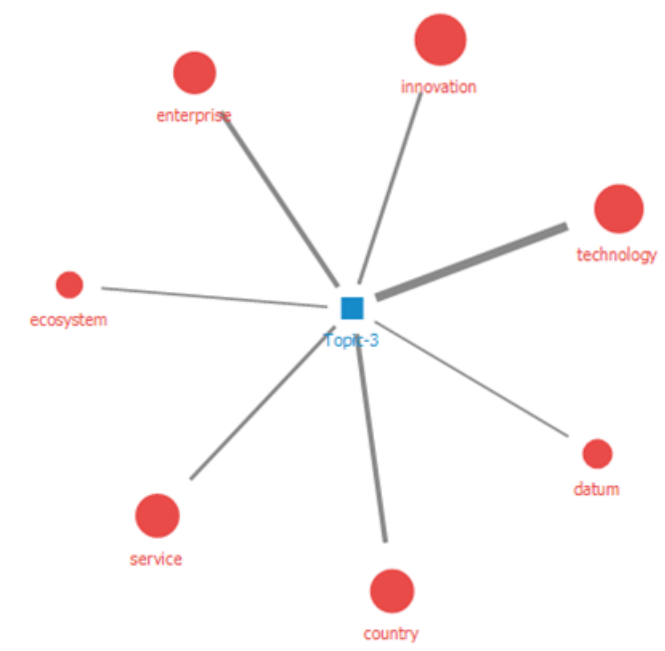

Figure 4: Topic 3: Social enterprise ecosystem 
Figure 5 shows the components of Topic 4. T opic 4 consists of education, university, engag ement, change, logic, society and community. This may be said to be a topic relating to ed ucation and social enterprises.

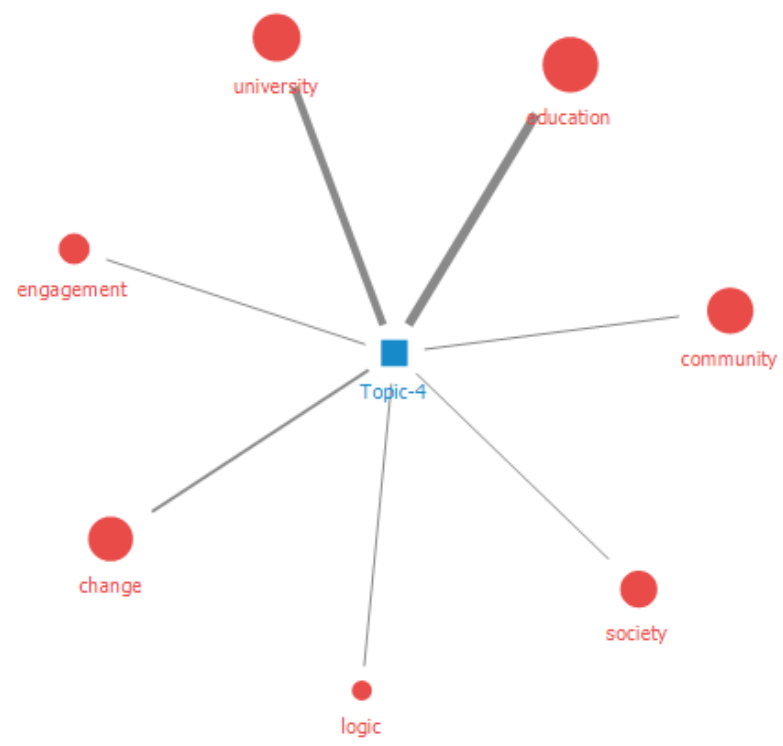

Figure 5 Topic 4: Education and social enter prise

Figure 6 shows the components of Topic 5. T opic 5 consists of market, capital, entrepreneu rship, entrepreneur, student and education. Thi s may be said to be a topic relating to social entrepreneurship.

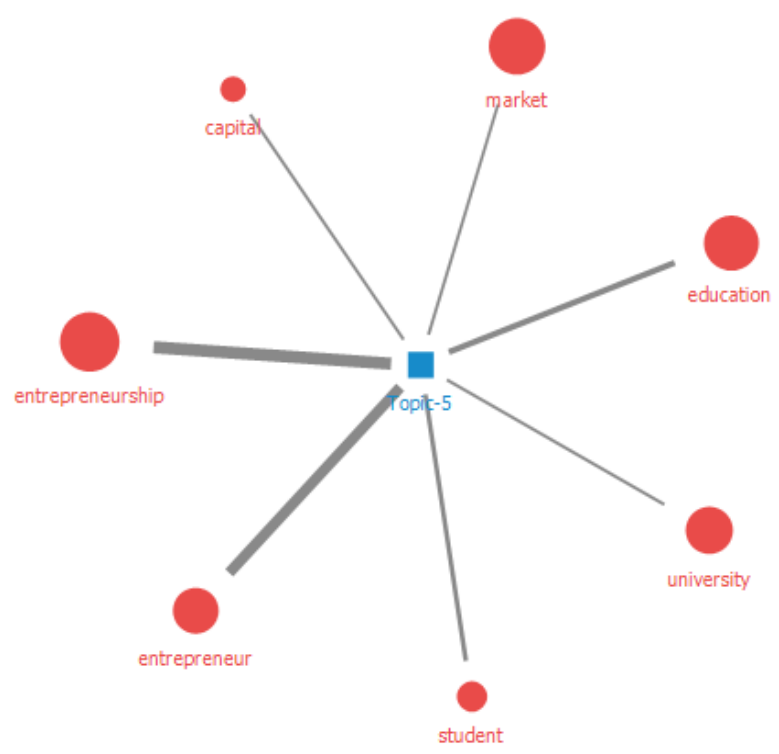

Figure 6: Topic 5: Social entrepreneurship
Figure 7 shows the components of Topic 6. T opic 6 consists of change, person, problem, $w$ orld, form, issue and right. This may be said to be a topic relating to environmental change $\mathrm{s}$ in social enterprise.

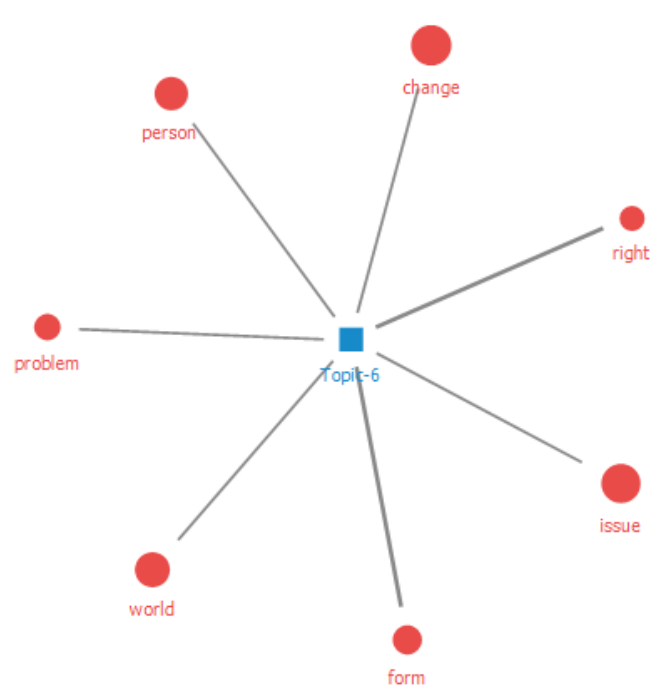

Figure 7: Topic 6: Environmental changes in social enterprise

Figure 8 shows the components of Topic 7. T opic 7 includes the words impact, health, com pany, CSR and framework. This may be said to be a topic relating to the impact of social enterprises.

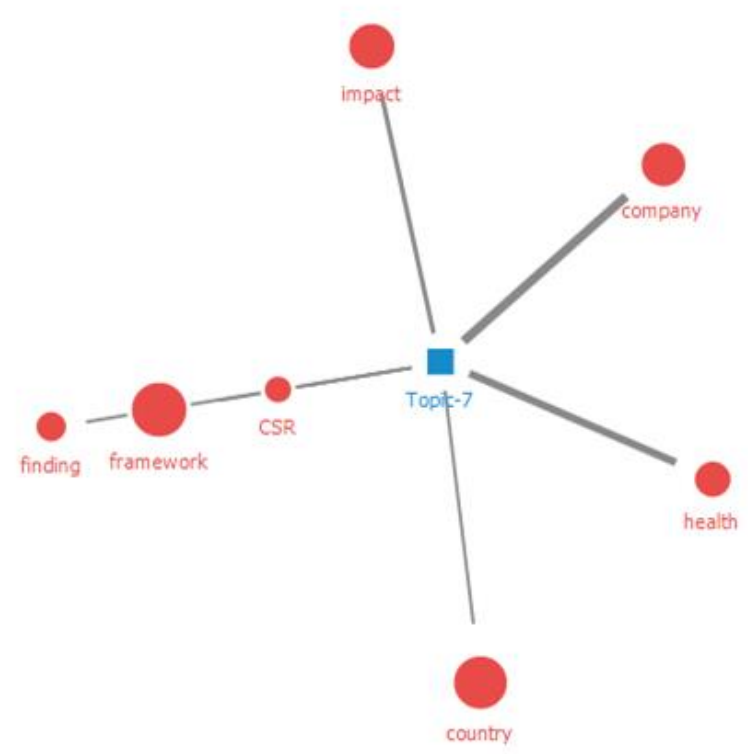

Figure 8: Topic 7: Impact of social enterprises 
Figure 9 shows the components of Topic 8. T opic 8 consists of strategy, chain, supply, mod el, concept, organization and state. This topic concerns the supply chain of social enterprise, and relates to the intellectual property rights $t$ o be addressed in this study.

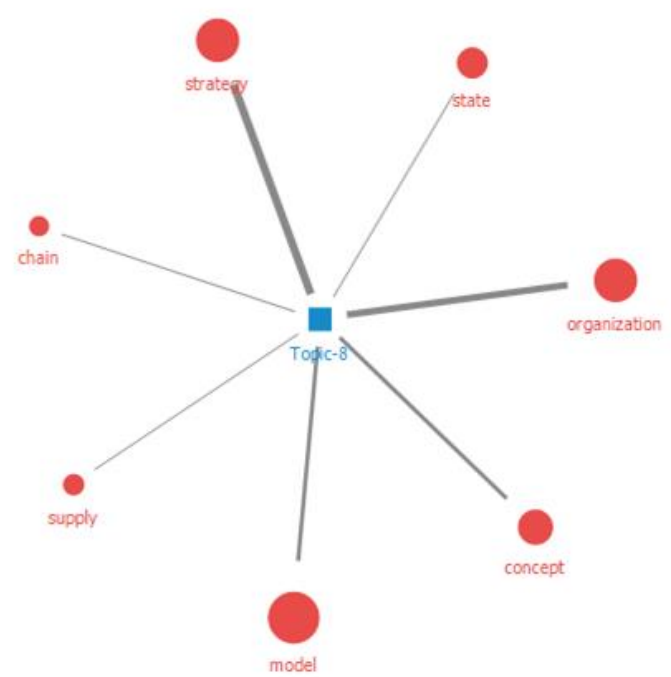

Figure 9 Topic 8: Supply chain of social ent erprises

Figure 10 shows the components of Topic 9. Topic 9 is made up of model, process, policy, market, value, innovation and management. $\mathrm{T}$ his may be called the 'social enterprise manag ement model'.

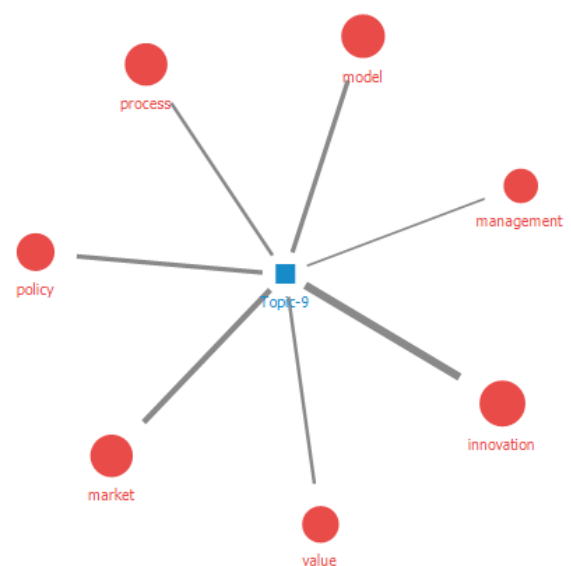

Figure 10 Topic 9: Management model of so cial enterprise

Figure 11 shows Topic 10. Topic 10 contains words such as sector, ONG, NGO, China an d food. This topic relates to the role of NGO $\mathrm{s}$, etc., that are necessary for the functioning of social enterprises. Therefore, we can call $\mathrm{T}$ opic 10 a topic relating to 'social enterprises and NGOs'.

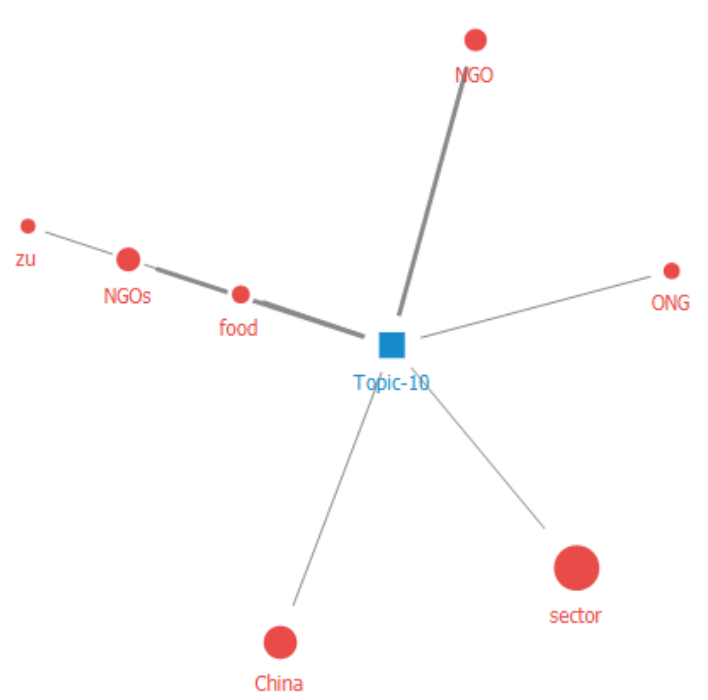

Figure 11 Topic 10: Social enterprises and N GOs

Figure 12 shows the results of a concentric ci rcle analysis of keywords relating to social en terprises and intellectual property rights. It ind icates that the words located at the centre of the concentric circles play an important role $i$ $\mathrm{n}$ the network.

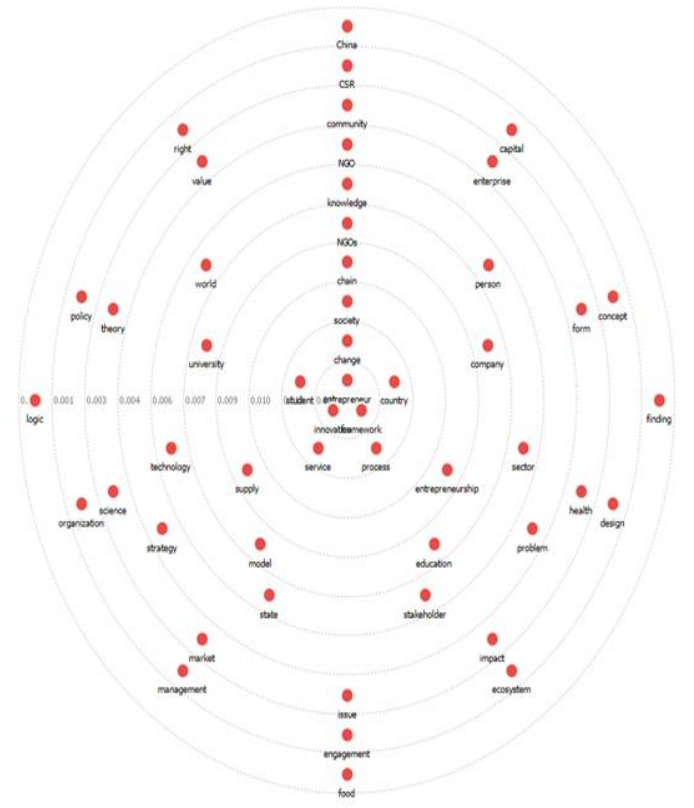

Figure 12 Concentric circle analysis result 
Figure 13 shows how important keywords acti ve in social enterprises and intellectual propert $\mathrm{y}$ networks are interrelated. This network is a simplified network, with features that show $\mathrm{k}$ ey relationships.

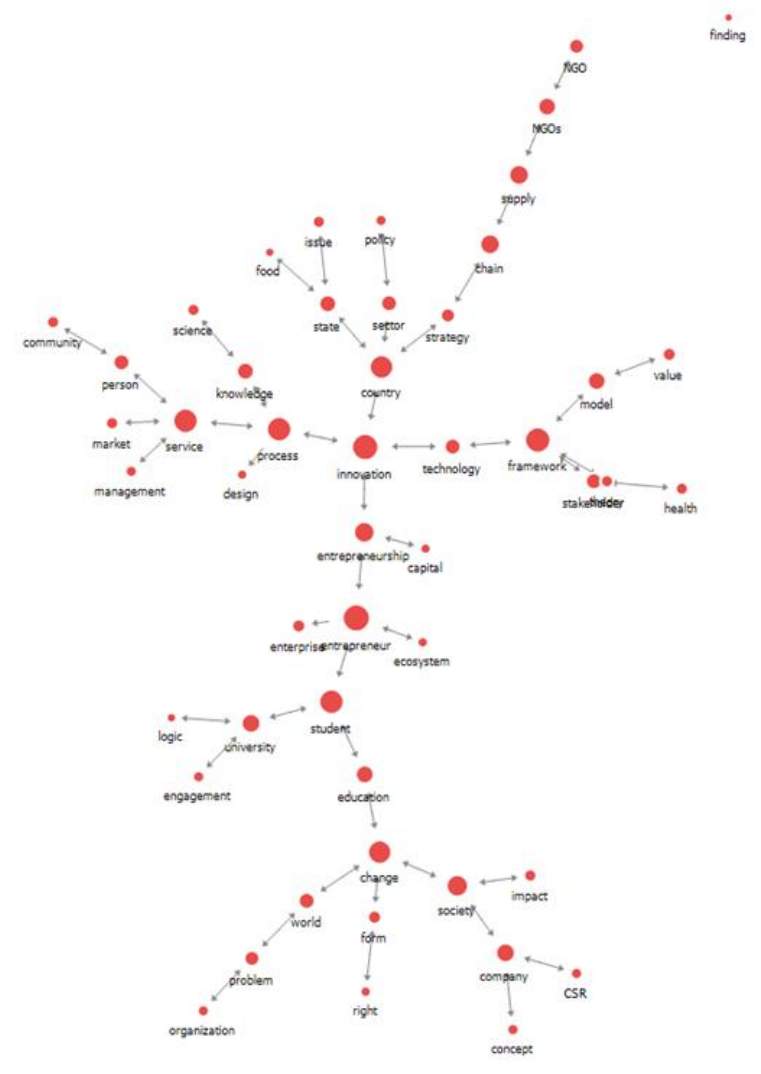

Figure 13 Simplified network

The results obtained from analysis of which w ords play an influential role in social enterpris es and intellectual property networks are show $\mathrm{n}$ in Table 2. The most influential keyword in the network is entrepreneur, followed by inn ovation. In other words, it may be said that e ntrepreneurs and innovation play an important role within social enterprises and intellectual $\mathrm{p}$ roperty networks.
Table 2 Degree centrality of keywords

\begin{tabular}{|c|c|c|c|}
\hline & & 1 & 2 \\
\hline & & In-Degree Centrality & Out-Degree Centrality \\
\hline 1 & entrepreneur & 0.014715 & 0.014715 \\
\hline 2 & innovation & 0.014032 & 0.014032 \\
\hline 3 & framework & 0.013467 & 0.013467 \\
\hline 4 & process & 0.013104 & 0.013104 \\
\hline 5 & student & 0.013065 & 0.013065 \\
\hline 6 & senvice & 0.012733 & 0.012733 \\
\hline 7 & change & 0.012254 & 0.012254 \\
\hline 8 & country & 0.012171 & 0.012171 \\
\hline 9 & society & 0.010596 & 0.010596 \\
\hline 10 & entrepreneurship & 0.009763 & 0.009763 \\
\hline 11 & chain & 0.009500 & 0.009500 \\
\hline 12 & supply & 0.009405 & 0.009405 \\
\hline 13 & company & 0.008772 & 0.008772 \\
\hline 14 & university & 0.008693 & 0.008693 \\
\hline 15 & education & 0.008043 & 0.008043 \\
\hline 16 & model & 0.007682 & 0.007682 \\
\hline 17 & NGOs & 0.007359 & 0.007359 \\
\hline 18 & state & 0.007281 & 0.007281 \\
\hline 19 & knowledge & 0.006732 & 0.006732 \\
\hline 20 & technology & 0.006539 & 0.006539 \\
\hline 21 & person & 0.006443 & 0.006443 \\
\hline 22 & world & 0.006339 & 0.006339 \\
\hline 23 & stakeholder & 0.006240 & 0.006240 \\
\hline 24 & sector & 0.006066 & 0.006066 \\
\hline 25 & problem & 0.005855 & 0.005855 \\
\hline 26 & NGO & 0.005455 & 0.005455 \\
\hline 27 & strategy & 0.005000 & 0.005000 \\
\hline 28 & enterprise & 0.004390 & 0.004390 \\
\hline 29 & form & 0.004299 & 0.004299 \\
\hline 30 & value & 0.003866 & 0.003866 \\
\hline
\end{tabular}

\subsection{Co-author pattern analysis}

The total number of authors of the 425 paper $\mathrm{s}$ is 777. As Table 3 indicates, Efrain Turban and Marian Eabrasu are the authors who hav e written the most papers relating to social en terprises and intellectual property rights. 
Table 3 Number of articles by authors

\begin{tabular}{|c|c|c|c|}
\hline & & 1 & 2 \\
\hline & & \# of article & Affiliation \\
\hline 1 & Efraim Turban & 6.0 & "University of Hawaii" \\
\hline 2 & Marian Eabrasu & 6.0 & "South Champagne Business School" \\
\hline 3 & ic Michael Laviole & 4.0 & "Toulouse Business School" \\
\hline 4 & Nagy K. Hanna & 4.0 & "University of Maryland" \\
\hline 5 & litt Nowshade Kak & 4.0 & "m" \\
\hline 6 & ristian Timmermar & 4.0 & "University of Chile" \\
\hline 7 & Jonatan Jelen & 3.0 & "Parsons The New School for Design" \\
\hline 8 & Linda Lai & 3.0 & "Macao Polytechnic Institute" \\
\hline 9 & Judy Strauss & 3.0 & "University of Nevada" \\
\hline 10 & Deborrah C. Turba & 3.0 & "Turban Company Inc." \\
\hline 11 & Ting-Peng Liang & 3.0 & "National Sun Yat-sen University" \\
\hline 12 & Jae Kyu Lee & 3.0 & "Yonsei University" \\
\hline 13 & David King & 3.0 & "JDA Software" \\
\hline 14 & Henk van den Belt & 3.0 & "Wageningen University" \\
\hline 15 & Michiel Korthals & 3.0 & "Wageningen University" \\
\hline 16 & Ellie Okada & 3.0 & "Boston Cancer Policy Institute" \\
\hline 17 & Iorah Hickling Gor & 3.0 & "The University of the West Indies" \\
\hline 18 & Barry D. Friedmar & 3.0 & "University of North Georgia" \\
\hline 19 & Aihua Yan & \multicolumn{2}{|c|}{2.0 / of Hong Kong, Tat Chee Ave, Hong Kong" } \\
\hline 20 & Matt Katzer & 2.0 & "'" \\
\hline 21 & Andrzej Klimczuk & 2.0 & "Warsaw School of Economics" \\
\hline 22 & uart James Richal & 2.0 & "University of Melbourne" \\
\hline 23 & Mary C. Lacity & 2.0 & "University of Missouri" \\
\hline 24 & Ananya Rajagopa & 2.0 & "Universidad Anáhuac México Sur" \\
\hline 25 & Jerzy Cieślik & 2.0 & "Kozminski University" \\
\hline 26 & Sandra K. Kauanu & 2.0 & "Florida Gulf Coast University" \\
\hline 27 & Eric Arseneau & 2.0 & "Florida Gulf Coast University" \\
\hline 28 & ynthia L. Sherma & \multicolumn{2}{|c|}{ 2.0 California State University Channel Islands' } \\
\hline 29 & Jing-Jyi Wu & 2.0 & "National Chengchi University" \\
\hline 30 & Ming-Jen $Y u$ & 2.0 & "National Chengchi University" \\
\hline
\end{tabular}

Figure 14 shows the result of word cloud ana lysis based on authors' names.

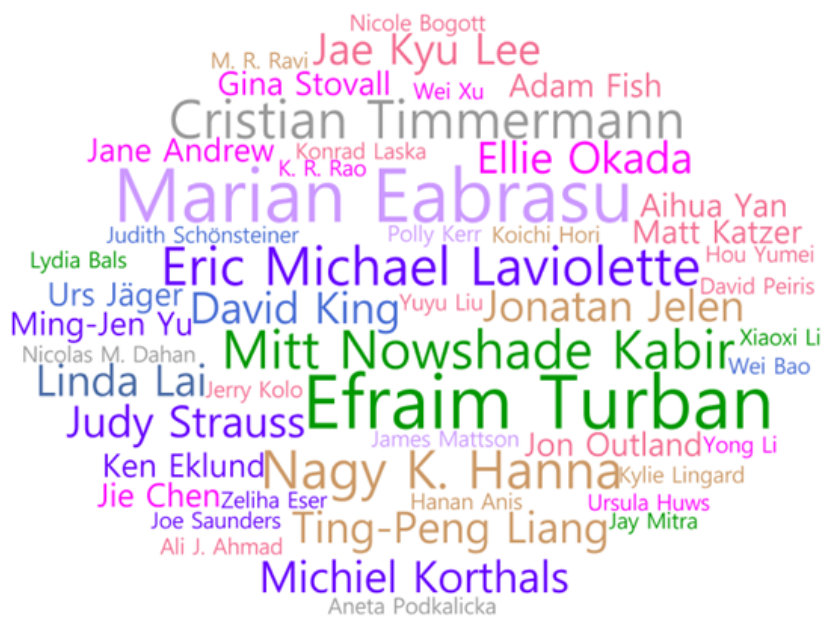

Figure 14 Results of word cloud analysis of authors

Figure 15 shows the activity patterns for these authors. As it indicates, some active writing activities relating to social enterprises and inte llectual property rights come from co-author $\mathrm{g}$ roups, and some authors appear to be writing articles individually. Papers relating to social e nterprises and intellectual property rights chara cteristically span several disciplines by their $n$ ature, and so it can be said that multi-discipli nary efforts are required. Nevertheless, the coauthor pattern appears to be rather basic, and so it can be said that more convergent and $\mathrm{m}$ ulti-disciplinary writing efforts are required.

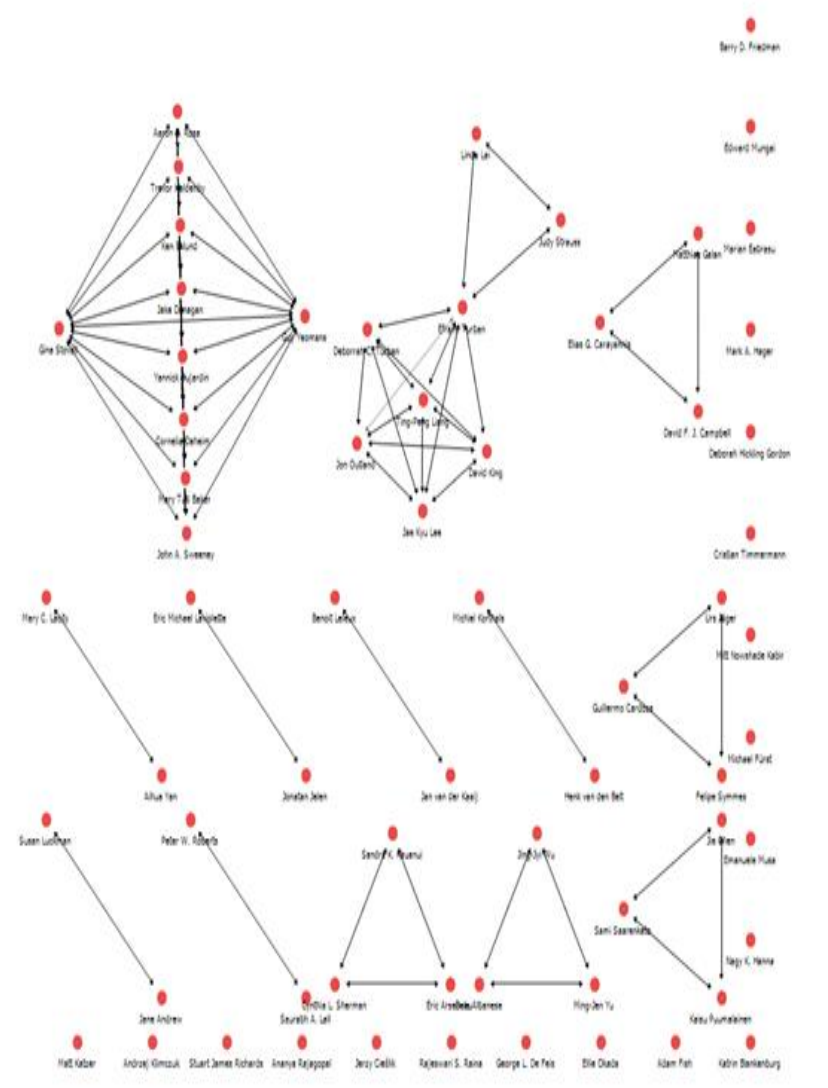

Figure 15 Co-author pattern

Figure 16 shows the results of concentric circl es analysis of the authors. Authors located in the centre of the concentric circles are those $\mathrm{s}$ howing active influence in the field of social 
enterprises and intellectual property rights.

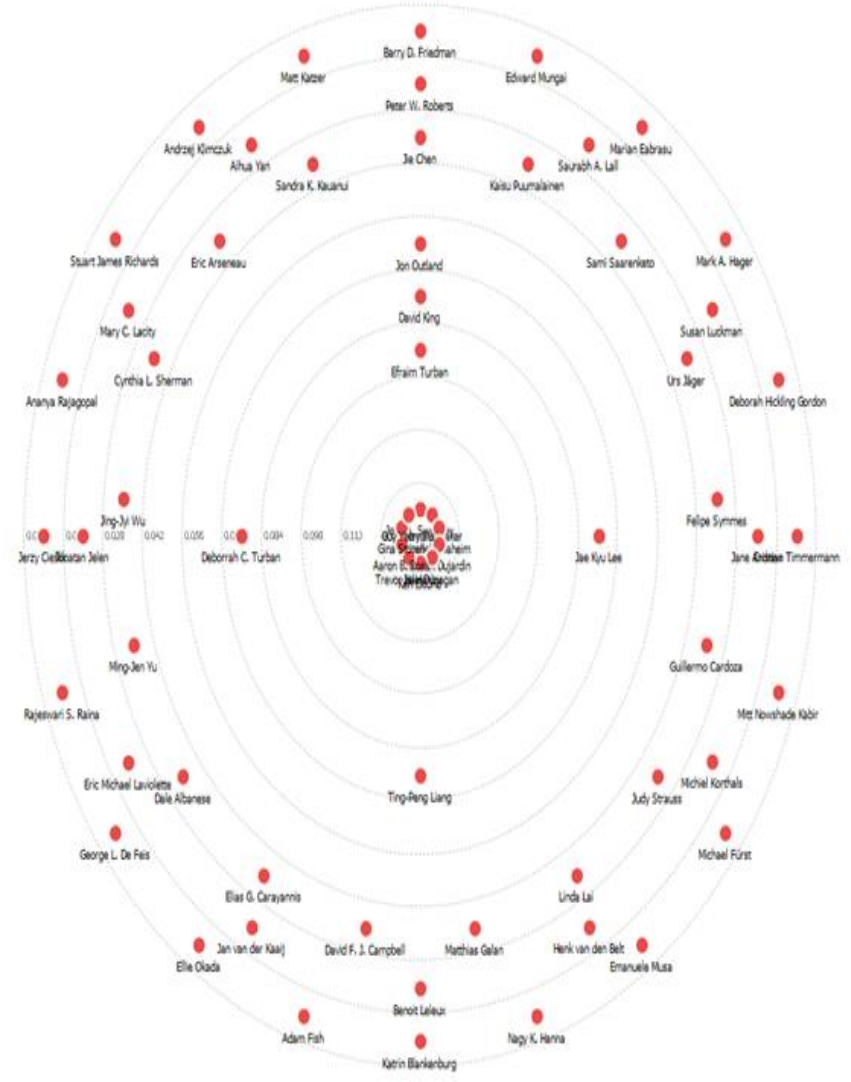

Figure 16 Results of concentric circles analys is of authors

Meanwhile, Table 4 shows the influence of th ese authors. The higher the in-degree centralit $y$, the more influential authors are in the field of social enterprise and intellectual property.

Table 4 Degree centrality of authors

\begin{tabular}{|c|c|c|c|}
\hline & & 1 & 2 \\
\hline & & In-Degree Centrality & Out-Degree Centrality \\
\hline 1 & Guy Yeomans & 0.140625 & 0.140625 \\
\hline 2 & Gina Stovall & 0.140625 & 0.140625 \\
\hline 3 & Aaron B. Rosa & 0.140625 & 0.140625 \\
\hline 4 & Trevor Haldenby & 0.140625 & 0.140625 \\
\hline 5 & Ken Eklund & 0.140625 & 0.140625 \\
\hline 6 & Jake Dunagan & 0.140625 & 0.140625 \\
\hline 7 & Yannick Dujardin & 0.140625 & 0.140625 \\
\hline 8 & Cornelia Daheim & 0.140625 & 0.140625 \\
\hline 9 & Mary Tuti Baker & 0.140625 & 0.140625 \\
\hline 10 & John A. Sweeney & 0.140625 & 0.140625 \\
\hline 11 & Efraim Turban & 0.093750 & 0.093750 \\
\hline 12 & Deborrah C. Turban & 0.078125 & 0.078125 \\
\hline 13 & Ting-Peng Liang & 0.078125 & 0.078125 \\
\hline 14 & Jae Kyu Lee & 0.078125 & 0.078125 \\
\hline 15 & David King & 0.078125 & 0.078125 \\
\hline 16 & Jon Outland & 0.062500 & 0.062500 \\
\hline 17 & Sandra K. Kauanui & 0.031250 & 0.031250 \\
\hline 18 & Eric Arseneau & 0.031250 & 0.031250 \\
\hline 19 & Cynthia L. Sherman & 0.031250 & 0.031250 \\
\hline 20 & Jing-Jyi Wu & 0.031250 & 0.031250 \\
\hline 21 & Ming-Jen $Y u$ & 0.031250 & 0.031250 \\
\hline 22 & Dale Albanese & 0.031250 & 0.031250 \\
\hline 23 & Elias G. Carayannis & 0.031250 & 0.031250 \\
\hline 24 & David F. J. Campbell & 0.031250 & 0.031250 \\
\hline 25 & Matthias Galan & 0.031250 & 0.031250 \\
\hline 26 & Linda Lai & 0.031250 & 0.031250 \\
\hline 27 & Judy Strauss & 0.031250 & 0.031250 \\
\hline 28 & Guillermo Cardoza & 0.031250 & 0.031250 \\
\hline 29 & Felipe Symmes & 0.031250 & 0.031250 \\
\hline 30 & Urs Jäger & 0.031250 & 0.031250 \\
\hline
\end{tabular}

\section{CONCLUSIONS}

In this study, papers published in 145 social $\mathrm{s}$ cience journals managed by the internationally renowned publishing company Springer were analysed using the text mining method. The ai $m$ of the study was to analyse what keywords are found in these papers, and what topics th ese keywords form. In addition, in reviewing $t$ he pattern displayed by co-authors of papers $r$ elating to social enterprises and intellectual $\mathrm{pr}$ operty rights, we focused on drawing out the implications for research in this field in the $\mathrm{f}$ uture. As a result of the analysis, several such implications can be drawn.

First, the research topics relating to social ent 
erprises and intellectual property rights can be said to constitute policy issues. From this po int of view, the results of the analysis allowe $\mathrm{d}$ us to classify these topics according to nine issues. These are: the management model of social enterprises; social enterprises and NGOs ; the supply chain of social enterprises; the $\mathrm{i}$ mpact of social enterprises; environmental cha nges in social enterprises; social entrepreneurs hip; social enterprise and education; the social enterprise ecosystem; and social enterprises a nd NGOs. These nine key issues formed a the oretical framework for the research. They repr esent areas that should be of great interest fro $\mathrm{m}$ the point of view of conducting business a ctivities that link social enterprises and intellec tual property rights. On the other hand, exami nation of the co-author patterns of authors wri ting about social enterprises and intellectual pr operty rights suggests that those employing $\mathrm{m}$ ulti-disciplinary characteristics should conduct more active joint research activities. Although such authors have achieved notable results to date, their engaging more actively in joint res earch activities should enhance the success of policies linking social enterprises and intellectu al property rights.

\section{ACKNOWLEDGEMENTS:}

This work was supported by the Ministry of Education of the Republic of Korea and the National Research Foundation of Korea (NRF-2019S1A5C2A03082775).

\section{REFERENCES}

[1] Blei, D.M. (2012). Probabilistic Topic Models. Communications of the ACM, 55(4), 77-84.

[2] Choi, Young-Chool \& Kim, Hak-Sil. (2018). Successful implementation of Korea' ODA projects: constructing causal loops and conducting sensitivity analysis. International Journal of Entrepreneurship, 22(1): 1-16.
[3] Corbett, S., \& Fikkert, B. (2012). When helping hurts: how to alleviate poverty without hurting the poor-and yourself, Chicago: Moody.

[4] Cornish, W., LLewelyn, D., \& Aplin, T. (2010). Intellectual Property: Patents, Copyright, Trademarks and Allied Rights (Seventh Ed). Sweet \& Maxwell.

[5] El-Harizi, K. and Klemick, H. (2007). Measuring and accounting for community capabilities in Kordofan, Sudan.

[6] Hurt, R. and Schuchman, R.(1996), The Economic Rationale of Copyright, American Economic Review, 56, Papers and Proceedings, 421-432.

[7] Hynes, W. \& Scott, S.. (2013). The evolution of Official Development Assistance. Paris: OECD.

[8] Markus, M., Wolf, M. and Bauer, S. (2018). Analyzing big data in social media: Text and network analyses of an eating disorder forum, International Journal of Eating Disorders, 51,7:.656-667.

[9] Mazzzurco, A. \& Jesiek, B. (2017). Five Guiding Principles to Enhance Community Participation in Humanitarian Engineering Projects, Journal of Humanitarian Engineering. 5(2): 89-101

[10] Polak, P., \& Warwick, M. (2013). The business solution to poverty: designing products and services for three billion new customers, San Francisco: Berrett-Koehler, Inc.

[11] Son, D.W. (2005). Social Network Analysis. Seoul: Kyungmunsa.

[12] Turner, B. L., Kim, H. \& Andersen, D. (2013). Improving coding procedures for purposive text data: researchable questions for qualitative system dynamic modeling, System Dynamics Review, 29(4): 253-263. 